\title{
Aktivitas antimikroba dan potensi penyembuhan luka ekstrak tembelekan (Lantana camara Linn.)
}

\author{
Hosea Jaya Edy ${ }^{1}$, Mauritius Lambertus Edy Parwanto ${ }^{2}$
}

\begin{abstract}
ABSTRAK
Salah satu tanaman yang digunakan secara turun-temurun dalam pengobatan adalah tembelekan (Lantana camara Linn.). L. camara Linn. mempunyai potensi yang besar untuk dikembangkan menjadi bahan baku obat karena jumlahnya yang sangat banyak dan mudah dibudidayakan.

Hasil ekstraksi L. camara Linn. diketahui mengandung alkaloid, terpenoid, flavonoid, steroid, polifenol, tanin. Ekstrak L. camara Linn. juga telah dibuat atau diformulasikan dalam berbagai jenis sediaan farmasi dalam bentuk semisolid seperti salep, krim maupun gel.

Ekstrak methanol daun L. camara Linn. memiliki aktivitas antibakteri terhadap Escherichia coli. Ekstrak daun L. camara Linn. menggunakan pelarut n-heksan, etil asetat, etanol juga memperlihatkan aktivitas antibakteri terhadap bakteri Gram positif (Staphylococcus pyogenesis dan Micrococcus luteus) dan bakteri Gram negatif (Vibrio cholera dan Shigella dysenteriae). Selain itu, sediaan farmasi ekstrak L. camara Linn. juga memperlihatkan aktivitas antimikroba terhadap Salmonella typhi, Vibrio alginolyctus dan S. aureus. Aktifitas antifungi dari ekstrak etanol daun L. camara Linn. juga telah diuji terhadap jamur Trichophyton concentricum L. Sediaan farmasi ekstrak L. camara Linn. juga telah diuji aktifitas penyembuhan luka pada kulit hewan uji.
\end{abstract}

Kata kunci: Lantana camara Linn., anti bakteri, anti fungi, penyembuhan luka pada kulit
${ }^{1}$ Program Studi Farmasi, Fakultas Matematika dan Ilmu Pengetahuan Alam,Universitas Sam Ratulangi, Manado, Indonesia

${ }^{2}$ Departemen Biologi Kedokteran, Fakultas Kedokteran Universitas Trisakti, Jakarta, Indonesia

\section{Korespondensi:}

Parwanto, MLE

Departemen Biologi Kedokteran, Fakultas Kedokteran Universitas Trisakti, Jalan Kyai Tapa, Kampus B, Grogol, Jakarta Barat 11440, Indonesia Email: edyparwanto@trisakti.ac.id

J Biomedika Kesehat 2020;3(1):33-38 DOI: $10.18051 /$ JBiomedKes.2020. v3.33-38

pISSN: 2621-539X / eISSN: 2621-5470

Artikel akses terbuka (open access) ini didistribusikan di bawah lisensi Creative Commons Attribution 4.0 International (CC-BY 4.0) 


\section{ABSTRACT}

\section{Antimicrobial activity and wound healing potential of tembelekan extract (Lantana camara Linn.)}

Tembelekan (Lantana camara Linn.) has been used for traditional medicine. L. camara Linn. great potential to be developed into herbal-medicine because the amount is very much and easily cultivated. $L$. camara Linn. extracted. known to contain alkaloid, terpenoids, flavonoids, steroids, polyphenols, tannins. Extract of $L$. camara Linn. has been made in various types of pharmaceutical preparations, including in the form of semisolid such as ointments, creams and gels.

$L$. camara Linn. leaf extract has been shown to have antibacterial activity against $E$. coli. Leaf extraction of $L$. camara Linn. using n-hexane, ethyl acetate, ethanol also showed antibacterial activity against Gram positive bacteria (S. pyogenesis and M. luteus) and Gram negative bacteria (Vibrio cholera and Shigella dysenteriae).

In addition, pharmaceutical preparations of $L$. camara Linn. extract also showed antimicrobial activity against S. typhi, V. Alginolyctus and S. aureus. L. camara Linn. leaf extract it has also been proven to be an antifungal function against Trichophyton concentricum L. Pharmaceutical preparations of L. camara Linn. extract has also been tested wound healing activity on the skin of test animals.

Keywords: Lantana camara Linn., anti bacterial, anti fungal, skin wound healing

\section{PENDAHULUAN}

Tanaman yang dipercaya memiliki khasiat obat sedang banyak diteliti untuk dimanfaatkan sebagai bahan baku obat baru. Indonesia sebagai daerah tropis memiliki banyak sekali tanaman obat yang dapat diteliti dan dipersiapkan menjadi bahan baku obat yang aman. Pemanfaatan tanaman obat telah berlangsung lama di Indonesia yang dilakukan secara turun-temurun dan hanya berdasarkan pengalaman empiris saja. Penelitian kandungan kimia, efikasi atau kemampuan mengobati dan juga sifat toksisitas dari tanaman obat perlu dilakukan untuk menjamin keamanan penggunaannya bagi masyarakat. ${ }^{(1)}$

Masyarakat Indonesia saat ini sedang giat memanfaatkan jamu atau tanaman sebagai pilihan utama dalam terapi pengobatan. Salah satu tanaman yang digunakan secara turun-temurun dalam pengobatan adalah tembelekan dengan nama ilmiah Lantana camara Linn ${ }^{(2)}$. (gambar 1). Tanaman L. camara Linn. dapat tumbuh subur dan cepat berkembang tanpa perawatan khusus pada tanah yang lembab. Pertumbuhan yang mudah dan cepat ini menyebabkan tanaman L. camara Linn.bersifat gulma yang dapat mengganggu pertumbuhan tanaman pertanian ${ }^{(3)}$. L. camara Linn. mempunyai potensi yang besar untuk dikembangkan menjadi bahan baku obat karena jumlahnya yang sangat banyak dan mudah dibudidayakan..$^{(2)}$

Tanaman L. camara Linn. secara tradisonal atau turun temurun telah banyak digunakan untuk pengobatan berbagai penyakit. Masyarakat secara tradisonal memanfaatkan daun tanaman L. camara Linn.untuk mengobati luka pada kulit. Daun $L$. camara Linn. juga dipercaya dapat mengobati penyakit kulit seperti panu, kadas dan kurap. Pemanfaatan daun L. camara Linn. pengobatan juga masih dilakukan secara sederhana yaitu hanya dengan menumbuk atau menghaluskan beberapa helai daun kemudian membalurkan pada daerah yang diobati. Selain dimanfaatkan dalam pengobatan tanaman L. camara Linn. juga dimanfaatkan sebagai pestisida alami dan
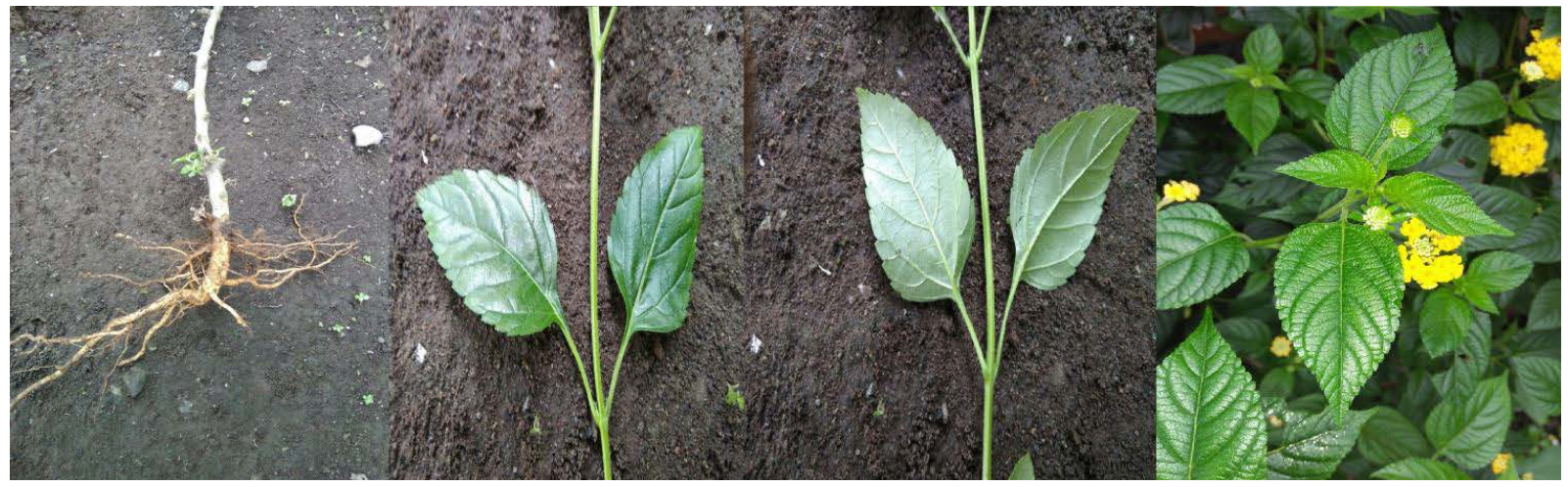

Gambar 1. Tumbuhan Lantana camara Linn.(2) 
juga sebagai antinyamuk oleh masyarakat dalam pertanian. ${ }^{(2,3,4)}$

\section{Kandungan kimia L.camara Linn.}

Daun tanaman L. camara Linn. mengandung banyak sekali metabolit sekunder atau zat kimia yang sangat penting bagi tanaman itu sendiri maupun akan dimanfaatkan sebagai bahan baku zat aktif obat. Fraksi n-heksane daun L. camara Linn. dilaporkan positif mengandung alkaloid, terpenoid, flavonoid dan steroid. Fraksi etil asetat dari daun L. camara Linn. positif mengandung senyawa golongan flavonoid, steroid dan polifenol/tanin. Fraksi etanol daun $L$. camara Linn. juga dilaporkan positif mengandung polifenol/tanin dan steroid. Ekstrak etanol daun $L$. camara Linn. juga positif mengandung senyawa metabolit sekunder golongan alkaloid, flavonoid, tanin dan steroid. ${ }^{(6,7)}$

Daun L. camara Linn. yang diekstrak menggunakan pelarut kloroform dan diuji menggunakan pereaksi ferri chlorida $\left(\mathrm{Fe}_{3} \mathrm{Cl}_{3}\right)$ memberikan hasil positif mengandung flavonoid. Hasil uji dengan pereaksi Libermann-Burchard memberikan hasil positif mengandung steroid. Pengujian menggunakan pereaksi Wagner menunjukkan bahwa ekstrak kloroform daun L. camara Linn. positif mengandung alkaloid. Pengujian kimia terhadap ekstrak klorofom daun L. camara Linn. dilakukan mengunakan bantuan alat spektroskopi IR dan spektroskopi NMR memberikan hasil bahwa kandungan kimia yang terkandung memiliki gugus fungsi yang mirip dengan senyawa flavanoid turunan flavon. ${ }^{(8)}$

Aktivitas antimikroba ekstrak L. camara Linn.

Ekstrak etanol dari daun L. camara Linn. yang dikoleksi dari Kabupaten Muna, Sulawesi Tenggara telah diuji aktivitas antibakteri menggunakan metode sumuran terhadap bakteri $S$. typhi. Ekstrak etanol daun L. camara Linn. dengan konsentrasi $12.5 \%$ memiliki aktivitas antibakteri yang kuat terhadap $S$. typhi dengan diameter zona hambat sebesar $6.6 \mathrm{~mm} .{ }^{(9)}$ Ekstrak methanol daun L. camara Linn. dengan konsentrasi 50, 25, 12.5 dan $6.25 \%$ terbukti memiliki aktivitas antibakteri terhadap E. coli. Konsentrasi $50 \%$ memiliki diameter zona hambat sebesar $28.401 \mathrm{~mm}$ dan konsentrasi $25 \%$ memiliki zona hambat sebesar $24.294 \mathrm{~mm}$. Konsentrasi ekstrak methanol daun L. camara Linn. $12.5 \%$ memiliki zona hambat terhadap E.coli sebesar $21.723 \mathrm{~mm}$ sedangkan untuk konsentrasi $6.25 \%$ memiliki zona hambat sebesar 17.635 mili meter (mm)..$^{(10)}$

Daun L. camara Linn. juga sudah diekstrak menggunakan tiga jenis pelarut berdasarkan perbedaan tingkat kepolaran yaitu n-heksan (pelarut non polar), etil asetat (pelarut semi polar), dan etanol (pelarut polar). Ketiga jenis ekstrak daun L. camara Linn. berdasarkan perbedaan tingkat kepolaran ini diuji aktivitas antibakteri terhadap bakteri Gram positif (S.pyogenesis dan Micrococcus luteus) dan bakteri Gram negative ( $V$. cholera dan $S$. dysenteriae). Ketiga jenis ekstrak (n-heksan, etil asetat, etanol) memiliki aktifitas antibakteri terhadap seluruh bakteri uji baik Gram positif maupun Gram negatif yang diujikan menggunakan metode sumuran. ${ }^{(1)}$ Aktivitas antibakteri ketiga jenis ekstrak daun $L$. camara Linn. tersaji pada Tabel 1.

Ekstrak etanol daun L. camara Linn. juga telah diujikan aktivitasnya terhadap bakteri Vibrio alginolyctus secara in vitro dengan metode sumuran. Bakteri $V$. alginolyctus adalah bakteri penyebab penyakit ice-ice pada tanaman rumput laut jenis Kappaphycus alvarezii. Konsentrasi ekstrak etanol daun L. camara Linn. dibuat menjadi 5 seri yaitu 1000, 1500, 2000, 5000 dan 10000 part per million (ppm). Masing-masing konsentrasi ekstrak memiliki aktivitas antibakteri terhadap $V$. alginolycus dengan ditandai terbentuknya zona jernih di sekitar pengujian. Konsentrasi

Tabel 1. Diameter zona hambat ekstrak daun $L$. camara Linn. berdasar tingkat kepolaran pelarut

\begin{tabular}{lcccc}
\hline \multirow{4}{*}{ Pelarut } & \multicolumn{4}{c}{$\begin{array}{c}\text { Diameter zona hambat } \\
\text { (mili meter=mm) }\end{array}$} \\
\cline { 2 - 5 } & $\begin{array}{c}\text { Staphylococcus } \\
\text { pyogenesis }\end{array}$ & Micrococcus luteus & $\begin{array}{c}\text { Vibrio } \\
\text { cholerae }\end{array}$ & $\begin{array}{c}\text { Shigella } \\
\text { dysenteriae }\end{array}$ \\
\hline n-heksan & 8.44 & 5.55 & 8.67 & 4.55 \\
Etil asetat & 19.22 & 12.55 & 17.00 & 6.22 \\
etanol & 20.89 & 12.00 & 18.56 & 5.33 \\
\hline
\end{tabular}


terendah dari ekstrak etanol daun L. camara Linn. yaitu $1000 \mathrm{ppm}$ memiliki diameter zona hambat sebesar $8.67 \mathrm{~mm}$ dan untuk konsentrasi terbesar yaitu 10000 ppm memiliki diameter zona hambat sebesar $14.33 \mathrm{~mm}$. Seluruh aktivitas antibakteri dari ekstrak daun L. camara Linn. masih jauh lebih kecil bila dibandingkan kontrol positif yaitu kloramfenikol $30 \mathrm{ppm}$ dengan diameter zona hambat sebesar $23.67 \mathrm{~mm}$. $^{(12)}$

Pengujian aktivitas antibakteri dari daun $L$. camara Linn. juga telah dilakukan terhadap isolat dari senyawa yang terkandung. Isolat golongan flavonoid yang identik dengan turunan flavon diisolasi dari ekstrak kloroform daun $L$. camara Linn. memiliki aktivitas antibakteri terhadap $S$. aureus dan E. coli. Diameter zona hambat dari isolat golongan flavonoid turunan flavon daun L. camara Linn. sebesar $8,97 \mathrm{~mm}$ terhadap $S$. aureus dan E. coli sebesar $10.60 \mathrm{~mm}$. ${ }^{(8)}$ Isolat golongan triterpenoid juga telah berhasil diisolasi dari ekstrak kloroform daun L. camara Linn. dan terbukti memiliki aktivitas antibakteri terhadap $S$. aureus dan E. coli. Diameter zona hambat yang terbentuk dari isolat golongan triterpenoid ekstrak kloroform daun L. camara Linn. sebesar $1.48 \mathrm{~mm}$ terhadap S. aureus dan $9.86 \mathrm{~mm}$ terhadap E. coli. (13)

Aktifitas antifungi dari ekstrak etanol daun L. camara Linn. juga telah diuji terhadap jamur Trichophyton concentricum menggunakan metode difusi paper disk. Jamur T. concentricum biasa menyebabkan penyakit kulit tinea imbricata atau dikenal dengan nama daerah kaskado. Ekstrak etanol daun L. camara Linn. dengan konsentrasi $25 \%$ memiliki diameter zona hambat sebesar $6.70 \mathrm{~mm}$, konsentrasi $50 \%$ dengan $7.40 \mathrm{~mm}$, konsentrasi $75 \%$ dengan $8.10 \mathrm{~mm}$. Konsentrasi terbesar dari pengujian aktivitas antifungi adalah $100 \%$ dengan nilai diameter zona hambat sebesar $8.60 \mathrm{~mm}$. Kontrol positif yang digunakan adalah flukonazol yang memberikan diameter zona hambat sebesar $26.30 \mathrm{~mm} .{ }^{(14)}$

\section{Aktivitas ekstrak $L$. camara Linn. yang telah diformulasi menjadi sediaan farmasi}

Ekstrak L. camara Linn. juga telah dibuat atau diformulasikan dalam berbagai jenis sediaan farmasi dalam bentuk semisolid seperti salep, krim maupun gel. Formulasi atau pembuatan sediaan farmasi dengan zat aktif ekstrak $L$. camara
Linn. memiliki tujuan akhir untuk mempermudah masyarakat dalam memanfaatkan bahan alam dalam terapi pengobatan. Pembuatan dalam bentuk sediaan farmasi untuk mempermudah pengujian aktifitas, kualitas serta keamanan dari sediaan dengan zat aktif yang siap digunakan dalam proses terapi penyembuhan..$^{(1,15)}$

Ekstrak etanol daun L. camara Linn. berhasil diformulasikan menjadi sediaan salep dengan kandungan ekstrak sebesar 20 dan 24\%. Dalam pengujian organoleptis, kedua formula salep memiliki bentuk semi solid dengan warna dan bau khas ekstrak Lantana camara. Salep yang dibuat seluruhnya juga memiliki homogenitas yang baik, dimana salep tidak mengumpal dan ekstrak menyatu secara merata. Salep yang dihasilkan memiliki nilai $\mathrm{pH} 4.5$ baik untuk formula $20 \%$ maupun $24 \%$ dan sesuai dengan nilai $\mathrm{pH}$ yang dipersyaratkan untuk sediaan topikal ( $\mathrm{pH} 4.5-6.5$ ). (16)

Ekstrak etanol daun L. camara Linn. dengan konsentrasi 3, 4 dan 5\% dibuat dalam bentuk krim dan telah diuji stabilitasnya dengan disimpan selama 1 tahun pada suhu ruang. Berdasarkan uji organoleptis ketiga formula krim memiliki bau khas ekstrak L. camara, berwarna hijau pucat dan berbentuk semisolid. Seluruh krim mampu mempertahankan kualitas secara organoleptis setelah disimpan selama satu tahun tanpa mengalami perubahan yang berarti. Seluruh krim memiliki nilai pH 6 ketika baru dibuat dan setelah disimpan selama satu tahun memiliki nilai $\mathrm{pH}$ yang sama seperti semula. Nilai daya sebar ketiga formula krim pada saat pembuatan tidak memenuhi parameter kualitas krim yaitu berdiameter $5-7 \mathrm{~cm}$. Pada saat pembuatan diameter daya sebar krim ekstrak L.camara Linn. 3\% adalah $2.44 \mathrm{~cm}$, krim $4 \%$ adalah $2.12 \mathrm{~cm}$ dan 2.29 $\mathrm{cm}$ untuk diameter daya sebar untuk krim 5\%. Krim yang dibuat terlalu kental sehingga akan kurang nyaman ketika diaplikasikan di kulit. ${ }^{(17,18)}$

Pengujian stabilitas juga dilakukan untuk mengukur kandungan zat aktif krim berdasarkan nilai total flavonoid ekuivalen quersetin dari ekstrak Lantana camara. Pengujian stabilitas suatu sediaan farmasi sangat penting untuk dilakukan guna memperoleh data kestabilan kandungan kimia dari sediaan tersebut ${ }^{(19)}$. Pada saat pembuatan krim L. camara Linn. 3\% memiliki kandungan flavonoid sebesar $132.8(\mathrm{mg} / \mathrm{L})$ dan setelah satu 
tahun menjadi $155.12(\mathrm{mg} / \mathrm{L})$ terjadi perubahan sebesar $85.6 \%$. Krim dengan kandungan ekstrak L. camara Linn. $5 \%$ memiliki nilai total flavonoid $170.62(\mathrm{mg} / \mathrm{L})$ pada saat pembuatan dan menjadi 311.86 (mg/L) setelah disimpan satu tahun terjadi perubahan sebesar $54.7 \%$. Krim dengan kandungan ekstrak L. camara Linn. 4\% memiliki stabilitas kandungan total flavonoid yang terbaik karena hanya mengalami perubahan sebesar $1.07 \%$ dari $231.96(\mathrm{mg} / \mathrm{L})$ pada saat pembuatan dan menjadi $215.40(\mathrm{mg} / \mathrm{L})$ setelah disimpan satu tahun. $^{(17)}$

Ekstrak L. camara Linn. juga telah diformulasikan menjadi sediaan salep dengan konsentrasi terkandung yaitu 5 dan $10 \%$. Kedua salep ekstrak L. camara Linn. ini telah diujikan aktifitas penyembuhan luka terbuka pada kulit hewan uji yang diinfeksi dengan bakteri $S$. epidermidis. Salep dengan kandungan ekstrak $L$. camara Linn. 5\% memberikan nilai jumlah koloni bakteri yang diisolasi dari bagian yang terluka lebih sedikit atau lebih baik dibanding salep 10\% dan kontrol sodium fusidat $2 \%$. Jumlah rata-rata koloni bakteri yang diisolasi pada hari ke-6 pada kelompok pengujian salep L. camara Linn. 5\% adalah 44.33 dan pada kelompok pengujian salep $10 \%$ adalah 86.67. Kelompok perlakuan kontrol negatif memiliki rata-rata jumlah koloni bakteri 144.57 dan pada kelompok kontrol positif sodium fusidat $2 \%$ adalah 83.67 . Aktivitas penyembuhan luka dari salep $L$. camara Linn karena kandungan kimianya seperti alkaloid, fenolik, flavonoid dan tannin. Senyawa kimia seperti alkaloid dan fenolik mencegah pertumbuhan bakteri pada area luka sehingga tidak terjadi infeksi yang memperparah proses penyembuhan luka. ${ }^{(20,21)}$ Aktivitas antioksidan dari senyawa flavonoid yang terkandung dalam salep juga membantu proses penyembuhan luka dengan mencegah terjadinya kematian sel pada proses penutupan luka. ${ }^{(22,23)}$ Pada proses penyembuhan luka dengan terapi salep L. camara Linn. 5\% juga menghasilkan pertumbuhan nilai DNA dan protein dari preparat penutupan luka yang lebih baik dibanding kelompok uji lainnya. $^{(2)}$

\section{KESIMPULAN}

Tumbuhan L. camara Linn. telah dimanfaatkan untuk pengobatan. Hasil ekstraksi L. camara Linn. diketahui mengandung alkaloid, terpenoid, flavonoid, steroid, polifenol, tanin.

Ekstrak L. camara Linn. juga telah dibuat atau diformulasikan dalam berbagai jenis sediaan farmasi dalam bentuk semisolid seperti salep, krim maupun gel. Sediaan farmasi ekstrak $L$. camara Linn. memperlihatkan aktivitas antimikroba antara lain S. typhi, E. coli, S. pyogenesis, M. luteus, $V$. cholera, S. dysenteriae, $V$. alginolyctus, S. aureus dan E. coli. Aktifitas antifungi dari ekstrak etanol daun $L$. camara Linn. juga telah diuji terhadap jamur Trichophyton concentricum L. Sediaan farmasi ekstrak $L$. camara Linn. juga telah diuji aktifitas penyembuhan luka pada kulit hewan uji.

\section{KONFLIK KEPENTINGAN}

Penulis menyatakan tidak ada konflik kepentingan.

\section{REFERENSI}

1. Edy HJ, Parwanto ME. Pemanfaatan tanaman Tagetes erecta Linn. dalam kesehatan. J Biomedika Kesehat. 2019;2(2):77-80. doi: 10.18051/ JBiomedKes.2019.v2.77-80

2. Parwanto MLE. Efficcacy of Lantana camara Linn. Leaf extracts ointment on dermal wound healing were infected with Staphylococcus epidermidis. Int J Basic Clin Pharmacol. 2017;6(3):503-510. doi: 10.18203/2319-2003.ijbcp20170457

3. Saputri DD, Bintang M, Pasaribu FH. Isolasi dan Karakterisasi Bakteri Endofit dari Tanaman Tembelekan (Lantana camara L.) sebagai Penghasil Senyawa Antibakteri. Current Biochemistry. 2015;2(2):77-89

4. Rahma N, Priskilla MS, Aryati D, et al. Using Tembelek (Lantana Camara) Plants As The Basic Material of Mosquito Repellent Lotion. Pelita. 2013;8(2):113-126

5. Dalimartha S. Atlas tumbuhan obat Indonesia. Jakarta: Trubus Agriwidya; 2007

6. Rijai L. Potensi tumbuhan tembelekan (Lantana camara Linn.) sebagai sumber bahan farmasi potensial. J Trop Pharm Chem. 2014;2(4):203-211. doi: $10.25026 /$ jtpc.v2i4.70

7. Mangela O, Ridhay A, Musafira M. Kajian aktivitas antioksidan ekstrak daun tembelekan (Lantana camara L) berdasarkan tingkat kepolaran pelarut [Internet]. KOVALEN. 2016;2(3):16-23. Available from: http://jurnal.untad.ac.id/jurnal/index.php/ kovalen/article/view/7531

8. Asma SN, Dini I, Danial M. Isolasi dan identifikasi senyawa metabolit sekunder ekstrak kloroform daun tembelekan (L. camara Linn.) dan uji potensi sebagai senyawa antibakteri alami [Internet]. Chemica. 2017;16(2):92-102. Available from: https://ojs.unm.ac.id/index.php/chemica/article/ view/4563

9. Muktadira U, Wicaksono S, Hartati H. Uji aktivitas ekstrak etanol daun tembelekan (L.camara L.) terhadap pertumbuhan bakteri Salmonella typhi. MEDULA. 2018;5(2):464-470

10. Lestari A, Jamhari M, Kundera IN. Daya hambat ekstrak daun tembelek (Lantana camara L.) terhadap pertumbuhan bakteri Escherichia coli 
[Internet]. E-JIP BIOL 2013;1(1):42-49. Available from: http://jurnal.untad.ac.id/jurnal/index.php/ EBiol/article/view/2685/1803

11. Lestari IP, Mappiratu M, Ruslan R, et al. Uji aktivitas antibakteri ekstrak daun tanaman tembelekan (Lantana camara Linn.) dari beberapa tingkat kepolaran pelarut [Internet]. KOVALEN. 2018;4(3):244-253. Available from: http://jurnal. untad.ac.id/jurnal/index.php/kovalen/article/ view/11850/9091

12. Tolanamy ES, Patadjai RS, Nur I. Potensi ekstrak daun tembelekan Lantana camara sebagai penghambat tumbuh bakteri pada rumput laut Kappaphycus alvarezii. J Sains dan Inov Perikan. 2017;1(1):1-8. doi: 10.33772/jsipi.v1i1.6590

13. Nurrahmaniah N, Side S, Dini I. Identifikasi dan uji bioaktivitas senyawa metabolit sekunder ekstrak kloroform daun tembelekan (Lantana camara Linn) [Internet]. Chemica. 2014;15(1):4152. Available from: https://ojs.unm.ac.id/chemica/ article/viewFile/4602/2647

14. Tikupasang A, Lantang D. Respon daya hambat ekstrak Lantana camara Linn (Verbenaceae) terhadap fungi Trichophyton concentricum L [Internet]. J Biol PAPUA. 2014;6(1):12-17. Available from: https://ejournal.uncen.ac.id/index. $\mathrm{php} / \mathrm{JBP} / \mathrm{article} / \mathrm{view} / 447$

15. Edy HJ, Marchaban M, Wahyuono S, et al. Pengujian aktivitas antibakteri hidrogel ekstrak etanol daun Tagetes erecta L [Internet]. J MIPA. 2019;8(3):96-98. Available from: https://ejournal. unsrat.ac.id/index.php/jmuo/article/view/25582

16. Parwanto ME, Senjaya H, Edy HJ. Formulasi salep antibakteri ekstrak etanol daun tembelekan (Lantana camara L.) [Internet]. Pharmacon. 2013;2(3):104-108. Available from: https:// ejournal.unsrat.ac.id/index.php/pharmacon/article/ view/2538

17. Mahardhitya MR, Parwanto ME. Krim ekstrak daun Lantana camara Linn. 4\% stabil setelah disimpan selama 1 tahun. J Biomedika Kesehat. 2018;1(1):50-57. doi: 10.18051/ JBiomedKes.2018.v1.50-57

18. Edy HJ, Marchaban M, Wahyuono S, et al Formulation and Evaluation of Hydrogel Containing Tagetes erecta L. Leaves Etanolic Extract. Int J Curr Innov Res. 2017;3:627-630.

19. Edy HJ, Marchaban, Wahyuono S, et al. Formulasi Dan Uji Sterilitas Hidrogel Herbal Ekstrak Etanol Daun Tagetes Erecta L [Internet]. Pharmacon. 2016;5(2):9-16. Available from: https://ejournal. unsrat.ac.id/index.php/pharmacon/article/ view/12163

20. Janani SR, Singaravadivel K. Screening of Phytochemical and Gc-Ms Analysis of Some Bioactive Constituents of Asparagus Racemosus. Int J Pharm Tech Res. 2014;6(2):428-432.

21. Devi J, Muthu AK. Gas Chromatography-Mass Spectrometry Analysis of Bioactive Constituents in the Ethanolic Extract of Saccharum Spontaneum Linn. Int J Pharm Pharm Sci. 2014;6(2):755-759.

22. Rajeswari J, Rani S. Gc-Ms Analysis of Phytochemical Compounds in the Ethanolic Extract of Root of Lawsonia Inermis Linn. Int J Pharm Tech Res. 2015;7(2):389-99

23. Edy HJ, Wahyuono S, Nugroho AE, et al. Characterization and Evaluation of Bioactive Compounds of Extract Ethanol Tagetes Erecta L. by GC-MS. Int J Chem Tech Res. 2017;10:172175 